\title{
Optimization of electrolysis conditions for ti film electrodeposition from lif-licl eutectic molten salt
}

\section{$\operatorname{AUTHOR}(S)$ :}

Unoki, Makoto; Norikawa, Yutaro; Yasuda, Kouji; Nohira, Toshiyuki

\section{CITATION:}

Unoki, Makoto ... [et al]. Optimization of electrolysis conditions for ti film electrodeposition from lif-licl eutectic molten salt. ECS Transactions 2020, 98(10): 393-400

\section{ISSUE DATE:}

2020

URL:

http://hdl.handle.net/2433/255865

\section{RIGHT:}

This is the Accepted Manuscript version of an article accepted for publication in ECS Transactions. The Electrochemical Society and IOP Publishing Ltd are not responsible for any errors or omissions in this version of the manuscript or any version derived from it. The Version of Record is available online at https://doi.org/10.1149/09810.0393ecst.; この論文は 出版社版でありません。引用の際には出版社版をご確認ご利用ください。; This is not the published version. Please cite only the published version. 


\title{
Optimization of Electrolysis Conditions for Ti Film Electrodeposition from LiF-LiCl Eutectic Molten Salt
}

\author{
Makoto Unoki ${ }^{\mathrm{a}}$, Yutaro Norikawa ${ }^{\mathrm{a}}$, Kouji Yasuda ${ }^{\mathrm{b}, \mathrm{c}, *}$, and Toshiyuki Nohira ${ }^{\mathrm{a}}$ \\ a Institute of Advanced Energy, Kyoto University, Uji 611-0011, Japan \\ ${ }^{\mathrm{b}}$ Agency for Health, Safety and Environment, Kyoto University, Kyoto 606-8501, Japan \\ ${ }^{\mathrm{c}}$ Graduate School of Energy Science, Kyoto University, Kyoto 606-8501, Japan \\ * Present address: Graduate School of Engineering, Kyoto University, \\ Kyoto 606-8501, Japan
}

The optimum conditions for electrodeposition of compact, smooth and adherent $\mathrm{Ti}$ films in $\mathrm{LiF}-\mathrm{LiCl}-\mathrm{Li}_{3} \mathrm{TiF}_{6}$ at $823 \mathrm{~K}$ were investigated. The $\mathrm{Li}_{3} \mathrm{TiF}_{6}$ was formed in situ in the melt via comproportionation reaction between $\mathrm{Li}_{2} \mathrm{TiF}_{6}$ and $\mathrm{Ti}$ powder. The solubility of $\mathrm{Li}_{3} \mathrm{TiF}_{6}$ was confirmed to be higher than $7.1 \mathrm{~mol} \%$ by cyclic voltammetry and ICP-AES measurement. Galvanostatic electrolysis was conducted on $\mathrm{Ni}$ plate substrates at various concentrations of $\mathrm{Li}_{3} \mathrm{TiF}_{6}(0.55,2.6,7.1 \mathrm{~mol} \%)$ and cathodic current density (50-1200 $\left.\mathrm{mA} \mathrm{cm}^{-2}\right)$. Ti films with smoother surface were obtained at higher $\mathrm{Li}_{3} \mathrm{TiF}_{6}$ concentration and lower current density. In the present study, the smoothest surface Ti films were obtained at $7.1 \mathrm{~mol}^{\%}$ of $\mathrm{Li}_{3} \mathrm{TiF}_{6}$ and $50 \mathrm{~mA} \mathrm{~cm}^{-2}$ of cathodic current density.

\section{Introduction}

Titanium is a metal having excellent properties such as high specific strength, high corrosion resistance and high biocompatibility. Therefore, titanium is utilized for aircraft components, chemical plants, medical components, etc. Furthermore, titanium is attractive metal in terms of its abundant resources. However, widespread use of titanium is prevented due to the high smelting cost and the poor workability. As a method to solve these problems, titanium plating is an attractive technique because superior surface properties of titanium can be utilized. Among titanium plating methods, electrolytic plating is a promising candidate because of the advantages of higher deposition rate and shape flexibility. Electrodeposition of titanium has been studied using aqueous solutions (1,2), organic solvents $(3,4)$, and high-temperature molten salts $(5-13)$ as electrolytes. Nevertheless, pure titanium can be electrodeposited only from high-temperature molten salts.

In previous studies, chlorides (5-7), fluorides (8-10), and fluoride-chloride mixtures (11-13) have been mainly used as molten salt electrolytes. Generally, fluoride molten salts are advantageous for electrodepositing compact and smooth titanium films. Robin et al. obtained comparatively compact and smooth films in LiF-NaF-KF melts at 873-923 K (9). In the case of fluoride-chloride mixtures, several researchers reported that Ti films having better morphology can be obtained from the melts with sufficient fluoride concentrations. Takamura et al. reported that the morphology of deposits was improved by adding $\mathrm{LiF}$ to $\mathrm{LiCl}-\mathrm{KCl}$ at $773 \mathrm{~K}(7)$. Song et al. reported that Ti metal with fine crystal grains was obtained when $\mathrm{KF}$ was added to $\mathrm{NaCl}-\mathrm{KCl}$ at $1073 \mathrm{~K}$ (13). Based on these reports, we have focused on the electrodeposition of titanium in fluoride-chloride mixtures 
consisting of single cations and having enough fluoride concentrations (14-17). We have already reported the electrochemical behaviors of $\mathrm{Ti}$ (III) ions and the electrodeposition of $\mathrm{Ti}$ in molten $\mathrm{KF}-\mathrm{KCl}(45: 55 \mathrm{~mol} \%, 923 \mathrm{~K})(14-16)$ and $\mathrm{LiF}-\mathrm{LiCl}(45: 55 \mathrm{~mol} \%, 923 \mathrm{~K})$ (17). We found that $\mathrm{LiF}-\mathrm{LiCl}$ has an advantage for electrodepositing smooth Ti films due to its lower melting point (774 $\mathrm{K}$ at the eutectic composition (18)). In general, smoother $\mathrm{Ti}$ films are expected to be obtained at lower temperature by suppressing the growth of crystal grains. Thus, $\mathrm{LiF}-\mathrm{LiCl}$ eutectic molten salt was selected to obtain Ti films with smooth surface.

In this study, we investigated the effect of $\mathrm{Li}_{3} \mathrm{TiF}_{6}$ concentration and current density on the morphology of electrodeposited $\mathrm{Ti}$ in $\mathrm{LiF}-\mathrm{LiCl}$ eutectic molten salt at $823 \mathrm{~K}$. First, the solubility of $\mathrm{Li}_{3} \mathrm{TiF}_{6}$ was investigated by cyclic voltammetry and inductive coupled plasma-atomic emission spectroscopy (ICP-AES) measurement. Second, galvanostatic electrolysis was conducted at various current densities at three different concentrations of $\mathrm{Li}_{3} \mathrm{TiF}_{6}(0.55,2.6,7.1 \mathrm{~mol} \%)$. The optimum conditions to obtain compact and smooth $\mathrm{Ti}$ films were evaluated by scanning electron microscopy (SEM), surface roughness $\left(S_{\mathrm{a}}\right)$, and $\mathrm{X}$-ray diffraction (XRD) measurement.

\section{Experimental}

Reagent-grade LiF (FUJIFILM Wako Pure Chemical Corp., >98.0\%) and LiCl (FUJIFILM Wako Pure Chemical Corp., >99.0\%) were separately dried under vacuum at $453 \mathrm{~K}$ for over $24 \mathrm{~h}$. They are further dried under vacuum at $773 \mathrm{~K}$ for $24 \mathrm{~h}$. The salts were mixed in the eutectic composition (molar ratio of $\mathrm{LiF}: \mathrm{LiCl}=30: 70$, melting point $=774 \mathrm{~K}$ (18), $300 \mathrm{~g}$ ) and loaded in a graphite crucible (Toyo Tanso Co., Ltd., outer diameter: 90 $\mathrm{mm}$, inner diameter: $80 \mathrm{~mm}$, and height: $120 \mathrm{~mm}$ ) or a $\mathrm{Ni}$ crucible (Chiyoda Industry Manufacturing Plant Co., Ltd., outer diameter: 98 mm, inner diameter: 96 mm, height: 102 $\mathrm{mm}$ ). The mixture in the crucible was placed at the bottom of a stainless-steel vessel in an airtight Kanthal container. The electrochemical measurements were conducted in dry Ar atmosphere at $823 \mathrm{~K}$ in a glove box. After blank measurements in molten LiF- LiCl, 0.50$5.0 \mathrm{~mol} \%$ of $\mathrm{Li}_{2} \mathrm{TiF}_{6}$ and $0.33-3.3 \mathrm{~mol} \%$ of Ti powder (Kojundo Chemical Laboratory Co., Ltd., 99.9\%) were added to the melt. Here, the synthetic method of $\mathrm{Li}_{2} \mathrm{TiF}_{6}$ was reported in our previous paper (17). The added amounts of Ti powder were approximately twice the amounts necessary to generate $\mathrm{Ti}(\mathrm{III})$ ions by comproportionation reaction between $\mathrm{Ti}(\mathrm{IV})$ ions and $\mathrm{Ti}(0)$ according to Eq. 1.

$$
\operatorname{Ti}(0)+3 \operatorname{Ti}(\mathrm{IV}) \rightarrow 4 \operatorname{Ti}(\mathrm{III})
$$

This reaction is also described as:

$$
6 \mathrm{LiF}+\mathrm{Ti}+3 \mathrm{Li}_{2} \mathrm{TiF}_{6} \rightarrow 4 \mathrm{Li}_{3} \mathrm{TiF}_{6}
$$

Electrochemical measurements and galvanostatic electrolysis were conducted using a three-electrode method with an electrochemical measurement system (Hokuto Denko 
Corp., HZ-7000). The working electrodes were Ni plate (Nilaco Corp., $10 \mathrm{~mm} \times 10 \mathrm{~mm}$, thickness: $0.1 \mathrm{~mm}, 99.95 \%$ ), Mo flag (Nilaco Corp., diameter: $3.0 \mathrm{~mm}$, thickness: $0.1 \mathrm{~mm}$, 99.95\%), Au flag (Nilaco Corp., diameter: $3.0 \mathrm{~mm}$, thickness: $0.1 \mathrm{~mm}, 99.98 \%$ ), and glasslike carbon rod (Tokai Carbon Co., Ltd., diameter: $3.0 \mathrm{~mm}$ ) electrodes. The structure of the flag electrodes was reported in our previous paper (19). Ti rods (Nilaco Corp., diameter: $3.0 \mathrm{~mm}, 99.5 \%$ ) were used as the counter and reference electrodes. In the blank measurement, a Pt wire (Nilaco Corp., diameter: $1.0 \mathrm{~mm}, 99.98 \%$ ) was used as the quasireference electrode. The potential of reference electrodes was calibrated with respect to a dynamic $\mathrm{Cl}_{2} / \mathrm{Cl}^{-}$potential determined by cyclic voltammetry on a glass-like carbon rod electrode. The melt temperature was measured using a type-K thermocouple. The electrolyzed samples on the Ni plates were soaked in distilled water for $30 \mathrm{~min}$ and $\mathrm{Al}\left(\mathrm{NO}_{3}\right)_{3}$ aqueous solution $\left(1.0 \mathrm{~mol} \mathrm{~L}{ }^{-1}\right.$, obtained from FUJIFILM Wako Pure Chemical Co., Ltd., $98.0 \%$ ) for $10 \mathrm{~min}$ at room temperature to remove the salt adhered on the deposits.

The surface and cross-section of the samples were observed by using scanning electron microscopy (SEM; Thermo Fisher Scientific Inc., Phenom Pro Generation 5). Before the observation of the cross section, the samples were cut at the center and embedded in acrylic resin. The samples were polished with emery papers, buffing compounds and a cross-section polisher (CP; Hitachi, Ltd., IM4000). The samples were then coated with Au using an ion-sputtering apparatus (Hitachi, Ltd., E-1010) to impart conductivity. The surface roughness $\left(S_{\mathrm{a}}\right)$ of the samples was also measured by SEM and calculated as the average of 5 points (the measurement conditions: shortest cut-off $\lambda_{s}=20$ $\mathrm{nm}$, longest cut-off $\lambda_{c}=240 \mu \mathrm{m}$, measured area $A=1.2 \times 1.2 \mathrm{~mm}$ ). The samples were also characterized by energy-dispersive X-ray spectroscopy (EDX; Thermo Fisher Scientific Inc., Phenom Pro Generation 5) and X-ray diffraction (XRD; Rigaku Corp., Ultima IV, $\mathrm{Cu}-\mathrm{K} \alpha$ line). A small portion of the molten salt was sampled by the suction method using a borosilicate glass tube (Pyrex ${ }^{\circledR}$, outer diameter: $6 \mathrm{~mm}$, inner diameter: $4 \mathrm{~mm}$ ) and dissolved in $\mathrm{HNO}_{3}$ aqueous solution ( $\mathrm{pH}$ 1, obtained from Tama Chemical Corp., AA-100 grade, $68 \mathrm{wt} \%$ ). The solution was analyzed by using inductive coupled plasma-atomic emission spectroscopy (ICP-AES; Hitachi, Ltd., SPECTRO BLUE) to determine the concentration of $\mathrm{Li}_{3} \mathrm{TiF}_{6}$ in the sampled molten salt.

\section{Result and discussion}

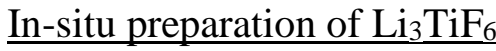

Prior to electrodeposition, the solubility of $\mathrm{Li}_{3} \mathrm{TiF}_{6}$ was investigated with cyclic voltammetry and ICP-AES measurement. As described in Eq. 2, the $\mathrm{Li}_{3} \mathrm{TiF}_{6}$ are synthesized in the molten $\mathrm{LiF}-\mathrm{LiCl}$ via the comproportionation reaction between $\mathrm{Li}_{2} \mathrm{TiF}_{6}$ and Ti powder.

Figure 1 (a) shows the cyclic voltammogram at a Au flag electrode in the positive potential region after the addition of $\mathrm{Li}_{2} \mathrm{TiF}_{6}(0.50-5.0 \mathrm{~mol} \%)$ and $\mathrm{Ti}$ powder $(0.33-3.3$ mol\%). The redox currents of $\mathrm{Ti}(\mathrm{III}) / \mathrm{Ti}(\mathrm{IV})$ were observed around $-0.8 \mathrm{~V} \mathrm{vs} . \mathrm{Cl}_{2} / \mathrm{Cl}^{-}$at each added amount of $\mathrm{Li}_{2} \mathrm{TiF}_{6}$. Figure 1 (b) shows the plots of peak current densities of each cyclic voltammogram against the added amounts of $\mathrm{Li}_{2} \mathrm{TiF}_{6}$. The peak current densities increased almost linearly as the $\mathrm{Li}_{2} \mathrm{TiF}_{6}$ was added. This result indicates that the 
added $\mathrm{Li}_{2} \mathrm{TiF}_{6}$ were almost completely dissolved up to $5.0 \mathrm{~mol} \%$ to form $\mathrm{Ti}(\mathrm{III})$ ions by the comproportionation reaction.

(a)

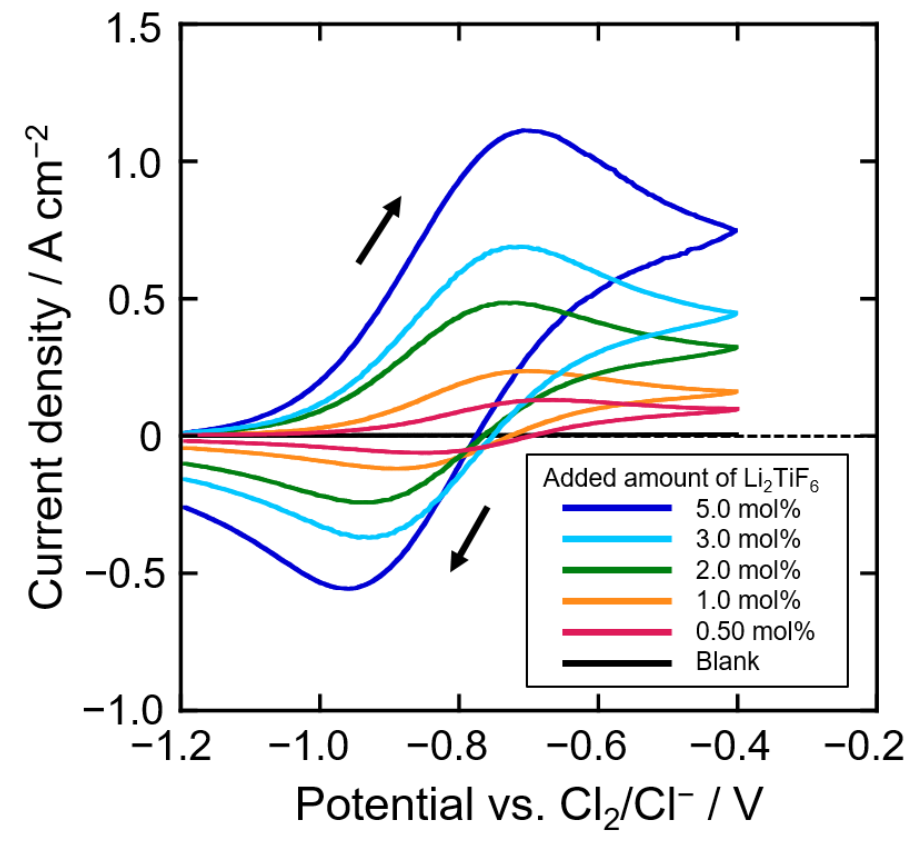

(b)

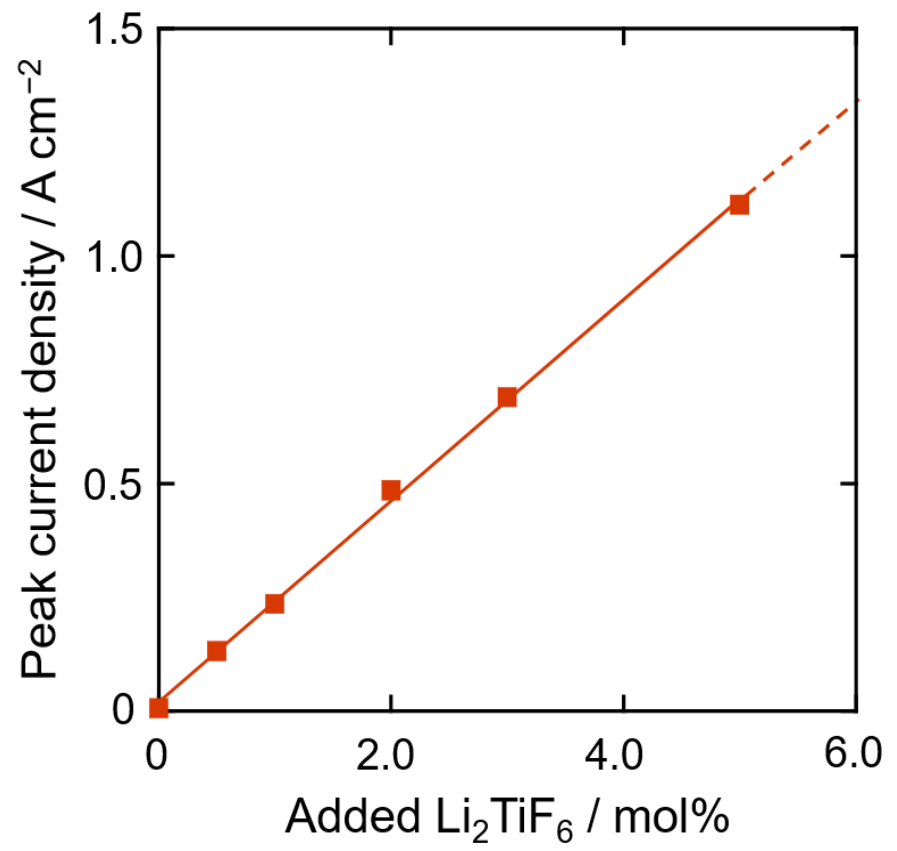

Figure 1. (a) Cyclic voltammograms at a Au flag electrode in molten $\mathrm{LiF}-\mathrm{LiCl}$ after adding various amounts of $\mathrm{Li}_{2} \mathrm{TiF}_{6}(0-5.0 \mathrm{~mol} \%)$ and $\mathrm{Ti}$ powder $(0-3.3 \mathrm{~mol} \%)$ at $823 \mathrm{~K}$. Scan rate: $0.50 \mathrm{~V} \mathrm{~s}^{-1}$. (b) Dependence of anodic peak current density on added amount of $\mathrm{Li}_{2} \mathrm{TiF}_{6}$.

Figure 2 shows the plots of the concentrations of $\mathrm{Li}_{3} \mathrm{TiF}_{6}$ determined by ICP-AES measurement against the added amounts of $\mathrm{Li}_{2} \mathrm{TiF}_{6}$. The black solid line indicates the theoretical value calculated from Eq. 2 and the red dots are the measured values. In this study, the concentration of $\mathrm{Li}_{3} \mathrm{TiF}_{6}$ is defined by the following equation. 


$$
\left[\mathrm{Li}_{3} \mathrm{TiF}_{6}\right]=n_{\mathrm{Li}_{3} \mathrm{TiF}_{6}} /\left(n_{\mathrm{LiF}}+n_{\mathrm{LiCl}}+n_{\mathrm{Li}_{3} \mathrm{TiF}_{6}}\right)
$$

Here, $n_{\mathrm{Li}_{3} \mathrm{TiF}_{6}}, n_{\mathrm{LiF}}$ and $n_{\mathrm{LiCl}}$ indicate the molar amounts of $\mathrm{Li}_{3} \mathrm{TiF}_{6}, \mathrm{LiF}$ and $\mathrm{LiCl}$ in the molten salt, respectively. Since $\mathrm{LiF}$ is consumed in the comproportionation reaction of Eq. 2 , the theoretical concentrations of $\mathrm{Li}_{3} \mathrm{TiF}_{6}$ are not simply four-thirds of the added amounts of $\mathrm{Li}_{2} \mathrm{TiF}_{6}$. Therefore, the theoretical value is not completely liner to the added amounts of $\mathrm{Li}_{2} \mathrm{TiF}_{6}$. As shown in Figure 2, the measured values were close to the theoretical ones up to $7.1 \mathrm{~mol} \%$ of $\mathrm{Li}_{3} \mathrm{TiF}_{6}$. Thus, the solubility of $\mathrm{Li}_{3} \mathrm{TiF}_{6}$ is confirmed to be more than 7.1 $\mathrm{mol} \%$.

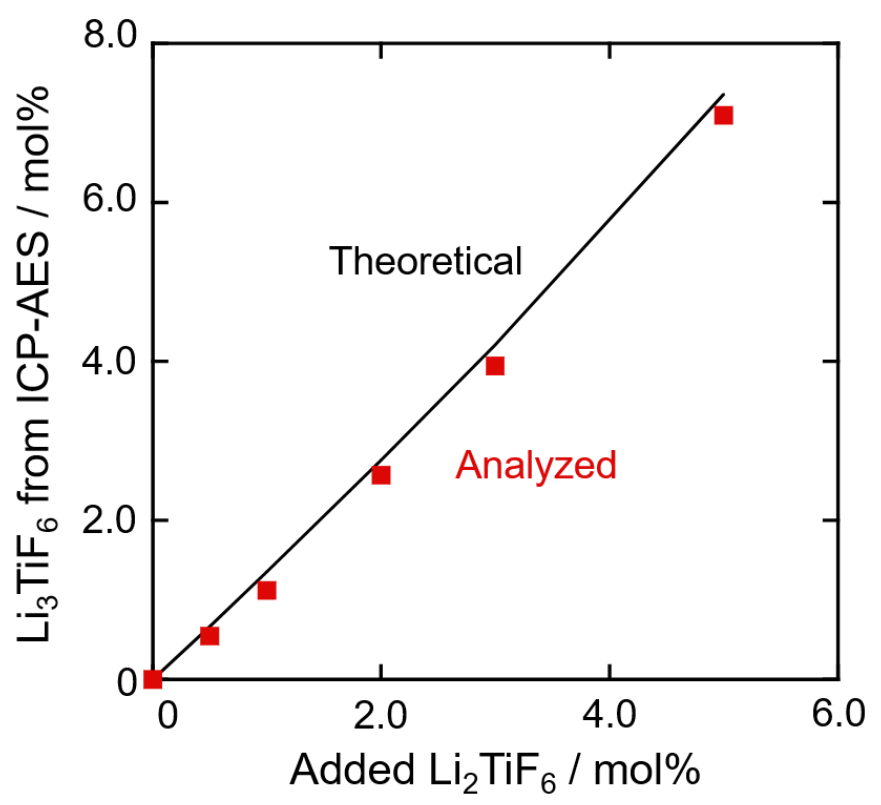

Figure 2. The concentration of $\mathrm{Li}_{3} \mathrm{TiF}_{6}$ determined by ICP-AES in molten $\mathrm{LiF}-\mathrm{LiCl}$ after adding various amounts of $\mathrm{Li}_{2} \mathrm{TiF}_{6}(0-5.0 \mathrm{~mol} \%)$ and $\mathrm{Ti}$ powder $(0-3.3 \mathrm{~mol} \%)$ at $823 \mathrm{~K}$.

\section{Electrodeposition of Ti films}

Galvanostatic electrolysis at Ni plate substrates was conducted under the conditions of various current densities $\left(50-1200 \mathrm{~mA} \mathrm{~cm}^{-2}\right)$ and $\mathrm{Li}_{3} \mathrm{TiF}_{6}$ concentrations $(0.55,2.6,7.1$ mol\%). Here, the reduction current is expressed as a positive value. The electric charge density was fixed at $60 \mathrm{C} \mathrm{cm}^{-2}$ for all electrolysis. The theoretical thickness of electrodeposited Ti films at $60 \mathrm{C} \mathrm{cm}^{-2}$ is $22 \mu \mathrm{m}$. Figure 3 shows optical images of the electrodeposited samples after washing with distilled water and $1 \mathrm{~mol} \mathrm{~L}^{-1} \mathrm{Al}\left(\mathrm{NO}_{3}\right)_{3}$ aqueous solution. XRD measurement confirmed that the electrodeposits were Ti. Compact and highly adherent Ti films were obtained at all $\mathrm{Li}_{3} \mathrm{TiF}_{6}$ concentrations at $50 \mathrm{~mA} \mathrm{~cm}$. As the concentration is increased, Ti films can be obtained even at higher current densities; Ti flims were obtained up to $200 \mathrm{~mA} \mathrm{~cm}{ }^{-2}$ at $2.6 \mathrm{~mol} \%$ of $\mathrm{Li}_{2} \mathrm{TiF}_{6}$ and up to $400 \mathrm{~mA} \mathrm{~cm}{ }^{-2}$ at $7.1 \mathrm{~mol} \%$. On the other hand, the morphology of the deposits changed to powder-like as 
the current densities further increased; the powder-like deposits were obtained at higher current density than $400 \mathrm{~mA} \mathrm{~cm}^{-2}$ at $2.6 \mathrm{~mol} \%$ and higher than $800 \mathrm{~mA} \mathrm{~cm}^{-2}$ at $7.1 \mathrm{~mol} \%$.

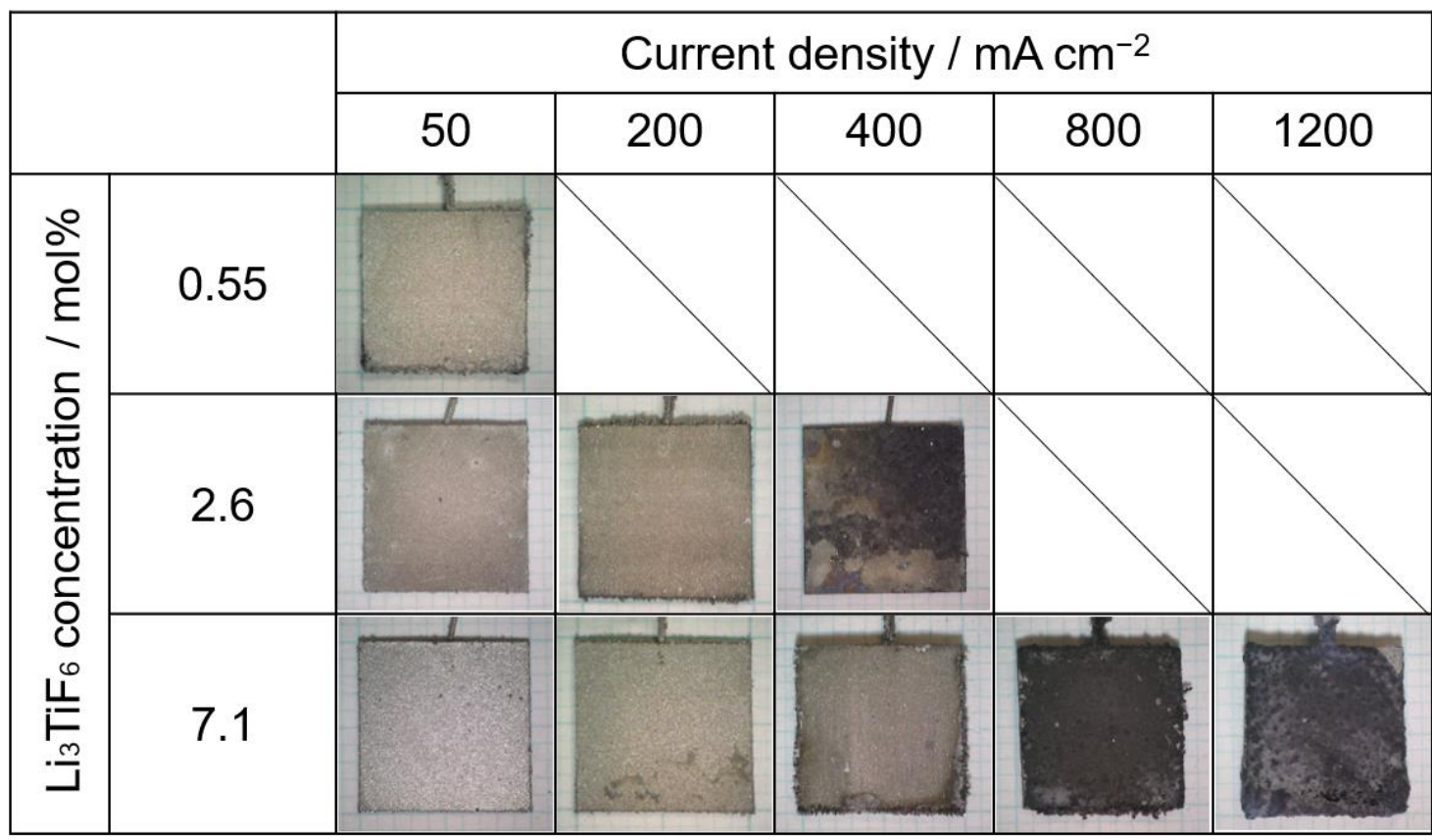

$5 \mathrm{~mm}$

Figure 3. Optical images of the samples obtained by galvanostatic electrolysis at Ni plates in molten $\mathrm{LiF}-\mathrm{LiCl}-\mathrm{Li}_{3} \mathrm{TiF}_{6}$ at $823 \mathrm{~K}$. Charge density: $60 \mathrm{C} \mathrm{cm}^{-2}$.

Figure 4 compares the surface/cross-sectional SEM images and surface roughness $\left(S_{\mathrm{a}}\right)$ at the same current density $\left(50 \mathrm{~mA} \mathrm{~cm}{ }^{-2}\right)$ at various $\mathrm{Li}_{3} \mathrm{TiF}_{6}$ concentrations. The formation of compact and adherent Ti film was also confirmed by the SEM images. The smoothness of the deposits was improved as the $\mathrm{Li}_{3} \mathrm{TiF}_{6}$ concentration increased. The smallest $S_{\mathrm{a}}(1.32 \mu \mathrm{m})$, which means the smoothest surface, was obtained at $7.1 \mathrm{~mol} \%$ of $\mathrm{Li}_{3} \mathrm{TiF}_{6}$.

Figure 5 shows the surface/cross-sectional SEM images and surface roughness $\left(S_{\mathrm{a}}\right)$ at the same $\mathrm{Li}_{3} \mathrm{TiF}_{6}$ concentration $(7.1 \mathrm{~mol} \%)$ at various current densities. In the case of at $400 \mathrm{~mA} \mathrm{~cm}^{-2}$, the compactness and adhesion were almost the same as those of $50 \mathrm{~mA} \mathrm{~cm}$. However, the roughness was increased and nodule electrodeposits were partially observed. At a very high current density of $1200 \mathrm{~mA} \mathrm{~cm}^{-2}$, the morphology of electrodeposits was powder-like and the adhesion was quite low. 


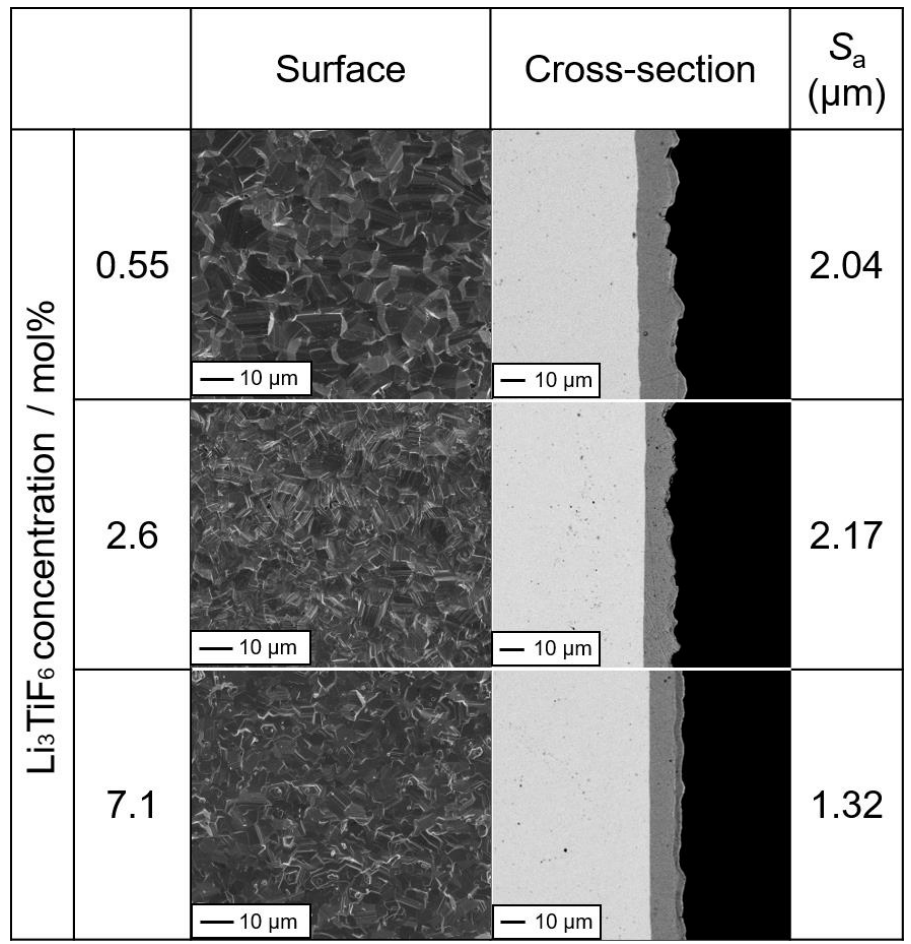

Figure 4. Surface/cross-sectional SEM images and surface roughness $\left(S_{\mathrm{a}}\right)$ of the samples obtained by galvanostatic electrolysis at $\mathrm{Ni}$ plates in $\mathrm{LiF}-\mathrm{LiCl}-\mathrm{Li}_{3} \mathrm{TiF}_{6}$ at $823 \mathrm{~K}$. Charge density: $60 \mathrm{C} \mathrm{cm}^{-2}$. Current density: $50 \mathrm{~mA} \mathrm{~cm}^{-2}$.

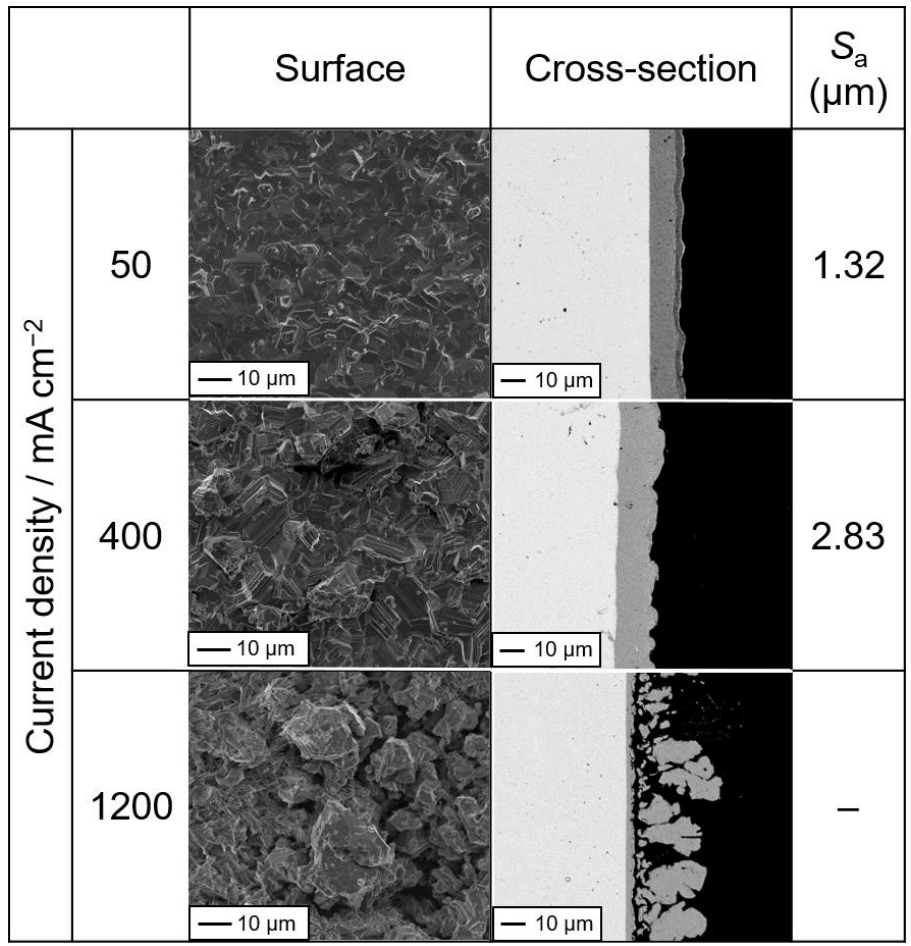

Figure 5. Surface/cross-sectional SEM images and surface roughness $\left(S_{\mathrm{a}}\right)$ of the samples obtained by galvanostatic electrolysis at $\mathrm{Ni}$ plates in $\mathrm{LiF}-\mathrm{LiCl}-\mathrm{Li}_{3} \mathrm{TiF}_{6}$ at $823 \mathrm{~K}$. Charge density: $60 \mathrm{C} \mathrm{cm}^{-2}$. $\mathrm{Li}_{3} \mathrm{TiF}_{6}$ concentration: $7.1 \mathrm{~mol} \%$. 


\section{Conclusion}

The optimum conditions for electrodepositing compact, smooth and adherent $\mathrm{Ti}$ films were investigated in $\mathrm{LiF}-\mathrm{LiCl}-\mathrm{Li}_{3} \mathrm{TiF}_{6}$ at $823 \mathrm{~K}$. The solubility of $\mathrm{Li}_{3} \mathrm{TiF}_{6}$ was confirmed to be more than $7.1 \mathrm{~mol} \%$ by cyclic voltammetry and ICP-AES measurement. Galvanostatic electrolysis was conducted on $\mathrm{Ni}$ plate substrates at various $\mathrm{Li}_{3} \mathrm{TiF}_{6}$ concentrations $(0.55,2.6,7.1 \mathrm{~mol} \%)$ and current densities $\left(50-1200 \mathrm{~mA} \mathrm{~cm}^{-2}\right)$. As a result, Ti films with smoother surface was obtained at higher $\mathrm{Li}_{3} \mathrm{TiF}_{6}$ concentration and lower current density. In the present electrolysis conditions, the smoothest surface Ti films were obtained at $7.1 \mathrm{~mol} \%$ of $\mathrm{Li}_{3} \mathrm{TiF}_{6}$ and $50 \mathrm{~mA} \mathrm{~cm}^{-2}$.

\section{Acknowledgments}

A part of this study was conducted as a collaborative research with Sumitomo Electric Industries, Ltd.

\section{References}

1. S. Morioka and A. Umezono, J. Jpn. Inst. Metals., 23, 71 (1959).

2. S. Kazuo and A. Kitani, Electrochemistry, 52, 302 (1984).

3. S. Biallozor and A. Lisowska, Electrochim. Acta, 25, 1209 (1980).

4. A. Lisowska and S. Biallozor, Electrochim. Acta, 27, 105 (1982).

5. M. B. Alpert, F. J. Schultz, and W. F. Sullivan, J. Electrochem. Soc., 104, 555 (1957).

6. G. M. Haarberg, W. Rolland, A. Sterten, and J. Thonstad, J. Appl. Electrochem., 23, 217 (1993).

7. H. Takamura, I. Ohno, and H. Numata, J. Jpn. Inst. Metals, 60, 388 (1996).

8. J. De Lepinay, J. Bouteillon, S. Traore, D. Renaud, and M. J. Barbier, J. Appl. Electrochem., 17, 294 (1987).

9. A. Robin, J. De Lepinay, and M. J. Barbier, J. Electroanal. Chem., 230, 125 (1987).

10. M. E. Sibert and M. A. Steinberg, J. Electrochem. Soc., 102, 641 (1955).

11. D. Wei, M. Okido, and T. Oki, J. Appl. Electrochem., 24, 923 (1994).

12. V. V. Malyshev and D. B. Shakhnin, Mater. Sci., 50, 80 (2014).

13. J. Song, Q. Wang, X. Zhu, J. Hou, S. Jiao, and H. Zhu, Mater. Trans., 55, 1299 (2014).

14. Y. Norikawa, K. Yasuda, and T. Nohira, Mater. Trans., 58, 390 (2017).

15. Y. Norikawa, K. Yasuda, and T. Nohira, Electrochemistry, 86, 99 (2018).

16. Y. Norikawa, K. Yasuda, and T. Nohira, J. Electrochem. Soc., 166, D755 (2019).

17. Y. Norikawa, K. Yasuda, and T. Nohira, J. Electrochem. Soc., 167, 082502 (2020).

18. J. Sangster and A. D. Pelton, J. Phys. Chem. Ref. Data, 16, 509 (1987).

19. K. Maeda, K. Yasuda, T. Nohira, R. Hagiwara, and T. Homma, J. Electrochem. Soc., 162, D444 (2015). 